\title{
The ability of haemolysins expressed by atypical enteropathogenic Escherichia coli to bind to extracellular matrix components
}

\author{
Caroline A Magalhães, Sarita S Rossato, Ângela S Barbosa, Thiago O dos Santos, \\ Waldir P Elias, Marcelo P Sircili, Roxane MF Piazza/+
}

Laboratório de Bacteriologia, Instituto Butantan, São Paulo, SP, Brasil

\begin{abstract}
Typical and atypical enteropathogenic Escherichia coli (EPEC) are considered important bacterial causes of diarrhoea. Considering the repertoire of virulence genes, atypical EPEC (aEPEC) is a heterogeneous group, harbouring genes that are found in other diarrheagenic E. coli pathotypes, such as those encoding haemolysins. Haemolysins are cytolytic toxins that lyse hostcells disrupting the function of the plasma membrane. In addition, these cytolysins mediate a connection to vascular tissue and/or blood components, such as plasma and cellular fibronectin. Therefore, we investigated the haemolytic activity of 72 aEPEC isolates and determined the correlation of this phenotype with the presence of genes encoding enterohaemolysins (Ehly) and cytolysin A (ClyA). In addition, the correlation between the expression of haemolysins and the ability of these secreted proteins to adhere to extracellular matrix (ECM) components was also assessed in this study. Our findings demonstrate that a subset of aEPEC presents haemolytic activity due to the expression of Ehlys and/or ClyA and that this activity is closely related to the ability of these isolates to bind to ECM components.
\end{abstract}

Key words: enteropathogenic Escherichia coli - atypical EPEC - enterohaemolysins -

cytolysin A - extracellular matrix components

Enteropathogenic Escherichia coli (EPEC), one of the six diarrheagenic E. coli (DEC) pathotypes, expresses an adherence factor that is chromosomally encoded by the eae gene (EPEC attaching and effacing), located within the locus for enterocyte effacement (LEE) pathogenicity island (McDaniel \& Kaper 1997). EPEC strains have been categorized into two subgroups, termed typical and atypical EPEC (aEPEC) (Kaper 1996).

In addition to the LEE pathogenicity island, typical EPEC (tEPEC) strains contain Per regulators and the EPEC adherence factor plasmid (EAF), which encodes the bundle-forming pili (BFP) that mediate localized adherence to epithelial cells (Donnenberg et al. 1992). EPEC strains lacking the EAF plasmid (Kaper 1996) and that do not express BFP have been designated aEPEC (Abe et al. 2009, Hernandes et al. 2009, Nara et al. 2010).

The aEPEC subgroup has been considered an emerging bacterial pathogen, associated with both sporadic cases and outbreaks of diarrhoea (Hernandes et al. 2009). Indeed, aEPEC isolates have been associated with diarrhoea in several countries, including Brazil (Afset et al. 2004, Robins-Browne et al. 2004, Franzolin et al. 2005, Nguyen et al. 2006, Bueris et al. 2007, Estrada-Garcia et al. 2009, Moreno et al. 2010). In Brazil, aEPEC is currently more prevalent than $\mathrm{tEPEC}$, which was previously

Financial support: FAPESP (04/12136-5, 06/07145-0) fellowship to SSR (06/58303-5)

CAM and SSR equally contributed to this work.

+ Corresponding author: roxane@butantan.gov.br

Received 6 August 2010

Accepted 1 December 2010 the most common bacterial agent in childhood endemic diarrhoea (Hernandes et al. 2009). These observations indicate that aEPEC constitutes an emerging DEC pathotype that requires epidemiological and virulence studies.

Many bacterial pathogens produce toxins that lyse host cells by disrupting the function of the plasma membrane. The majority of these cytolytic toxins are poreforming proteins and several of them are important virulence factors for their parent bacteria (Alouf 2001). In $E$. coli, several different pore-forming cytolysins have been identified. The most extensively studied is $\alpha$-haemolysin (HlyA), which is produced by many uropathogenic $E$. coli strains. Its contribution to virulence has been shown in several animal models (Hull et al. 1981, Hacker et al. 1983).

A toxin related to HlyA, enterohaemorrhagic E. coli (EHEC-HlyA, denoted Ehx), is encoded by ehx genes that are located on a virulence plasmid belonging to EHEC (Bauer \& Welch 1996, Schmidt et al. 1996). Ehx has been identified in EHEC strains of serotype O157:H7 and is also present in most EHEC strains belonging to other serotypes, such as $\mathrm{O} 26: \mathrm{H} 11 / \mathrm{H}^{-}$and $\mathrm{O} 103: \mathrm{H} 2$ (see Jenkins et al. 2008 for a review).

In addition, it has been previously reported that EPEC O26: $\mathrm{H}^{-}$isolates are associated with a type of haemolysin, termed enterohaemolysin (Ehly) because of its association with enteric diseases, that is phenotypically, genetically and serologically unrelated to the previously described haemolysins (Beutin et al. 1989). Actually, the bacteriophage-associated proteins Ehlyl and Ehly2 in these isolates are not haemolysins per se. Instead, they induce the release of cytolysin A (ClyA) (Oscarsson et al. 2002a), a pore-forming haemolysin produced by E. coli $\mathrm{K}-12$ that is unrelated to HlyA. 
ClyA is a $34-\mathrm{kDa}$ protein that is encoded by a chromosomal gene named clyA (also referred to as $h l y E$ and sheA) (Oscarsson et al. 1996, del Castillo et al. 1997). In addition to $E$. coli $\mathrm{K}-12$, this haemolysin has also been shown to be produced by pathogenic $E$. coli, such as Shiga-toxin producing $E$. coli (STEC), enteroinvasive E. coli (EIEC), enteroaggregative $E$. coli (EAEC), enterotoxigenic $E$. coli (ETEC) (Ludwig et al. 1999) and extraintestinal $E$. coli isolates (ExPEC) (Kerényi et al. 2005).

Haemolysins also play an important role in the pathogenesis of several other Gram-negative bacteria and they mediate adhesion to vascular tissue and/or blood components, such as plasma and cellular fibronectin (Lowrance et al. 1988). Therefore, in this study we investigated the expression of haemolysins, the presence of their encoding genes in aEPEC and the relationship between the expression and binding of these secreted proteins to extracellular matrix (ECM) macromolecules.

\section{MATERIALS AND METHODS}

Bacterial strains - Seventy-two aEPEC isolates were used in this study, all of which have been previously characterized by polymerase chain reaction (PCR) analysis as containing the eae gene and lacking the EAF plasmid, the $b f p A$ gene and BFP expression (Bueris et al. 2007, Abe et al. 2009, Nara et al. 2010). These isolates belong to a wide range of serotypes and exhibit distinct patterns of adhesion to HEp-2 cells (Abe et al. 2009). Isolates C3888 $\left(\mathrm{O} 26: \mathrm{H}^{-}\right)($Beutin et al. 1988) and BA86 (O76:H19) (Bueris et al. 2007) were used as prototypes for Ehly expressing and non-expressing isolates, respectively.

Culture media and growth conditions - The following media were used: tryptic soy broth (TSB) $(1.7 \%$ casein, $0.5 \% \mathrm{NaCl}, 0.25 \% \mathrm{~K}_{2} \mathrm{HPO}_{4}, 0.3 \%$ peptone and $0.25 \%$ glucose), Evans medium (EM) $(0.15 \%$ yeast extract, $0.25 \% \mathrm{NaCl}, 0.871 \% \mathrm{KH}_{2} \mathrm{PO}_{4}, 0.0005 \% \mathrm{MnCl}_{2} .4 \mathrm{H}_{2} \mathrm{O}$, $0.005 \% \mathrm{MgSO}_{4}$ and $0.0005 \% \mathrm{FeCl}_{3} .6 \mathrm{H}_{2} \mathrm{O}$ ) and minimal medium (MM) $\left(6.4 \% \mathrm{Na}_{2} \mathrm{HPO}_{4} .2 \mathrm{H}_{2} \mathrm{O}, 0.25 \% \mathrm{NaCl}\right.$, $0.5 \% \mathrm{NH}_{4} \mathrm{Cl}, 15 \%$ casein and $2 \%$ lactose). All reagents were purchased from Difco. Bacterial isolates were cultured in $3 \mathrm{~mL}$ of TSB, EM or MM with shaking at $150 \mathrm{rpm}$ for $18 \mathrm{~h}$ at $37^{\circ} \mathrm{C}$. Stock cultures were made by taking aliquots corresponding to one optical density bacterial growth, supplementing them with glycerol to $80 \%(\mathrm{~V} / \mathrm{V})$ and storing them in cryotubes at $-80^{\circ} \mathrm{C}$.

Haemolytic activity on sheep blood agar plates - To detect haemolytic activity, bacteria were spotted onto blood agar plates directly from stock cultures or after pre-culturing in different liquid media (TSB, EM or MM). Two microliters of the growth suspension were spotted onto blood agar plates supplemented with $10 \mathrm{mM}$ calcium chloride and containing 5\% defibrinated sheep erythrocytes washed in phosphate buffer saline (PBS) $\mathrm{pH}$ 7.4. The plates were examined after $24 \mathrm{~h}$ of incubation at $37^{\circ} \mathrm{C}$ for the presence of lysis zones around areas of bacterial growth (Beutin et al. 1989).

Detection of ehxA, ehly and sheA genes - The 72 aEPEC isolates were tested for the presence of $e h x A$, ehlyA and sheA genes by PCR. All primers used in this study were based on conserved regions of these genes. The ehxA gene was amplified with forward (ATGACAGTAAATAAAATAAAGAAC) and reverse (TCAGACAGTTGTCGTTAAAGTTG) primers (Cookson et al. 2007) using the following amplification cycle: $30 \times\left(95^{\circ} \mathrm{C} / 45 \mathrm{sec}, 53^{\circ} \mathrm{C} / 30 \mathrm{sec}, 72^{\circ} \mathrm{C} / 2 \mathrm{~min}\right), 72^{\circ} \mathrm{C} / 7$ min. The ehlyA gene was amplified with forward (GCCGGGCACGTCTGTTC) and reverse (GCGCGGTGCCGTTTCCTG) primers based on the published sequence (GenBank accession X70047), using the following amplification cycle: $30 \times\left(94^{\circ} \mathrm{C} / 45 \mathrm{sec}, 64^{\circ} \mathrm{C} / 30 \mathrm{sec}, 72^{\circ} \mathrm{C} / 2\right.$ $\mathrm{min}), 72^{\circ} \mathrm{C} / 8 \mathrm{~min}$. The she $A$ gene was amplified with forward (GAGGCGAATGATTATGACTG) and reverse (ACTTCAGGTACCTCAAAGAG) primers (Kerényi et al. 2005) using the following amplification cycle: $30 \mathrm{x}$ $\left(94^{\circ} \mathrm{C} / 1 \mathrm{~min}, 58^{\circ} \mathrm{C} / 1 \mathrm{~min}, 72^{\circ} \mathrm{C} / 2 \mathrm{~min}\right), 72^{\circ} \mathrm{C} / 8 \mathrm{~min}$. The amplified fragments were analyzed by electrophoresis in $0.8 \%$ agarose gels, resulting in a $2,997 \mathrm{bp}$ fragment, a $712 \mathrm{bp}$ fragment and a $920 \mathrm{bp}$ fragment for $e h x A$, for ehly and for sheA genes, respectively.

Anti-supernatant polyclonal antibody - The haemolytic phenotype was determined in both non-disrupted pellet and concentrated supernatant (50X) fractions of the C3888 strain. The supernatant was obtained by growing the $\mathrm{C} 3888$ isolate in $50 \mathrm{~mL}$ of TSB while shaking at $150 \mathrm{rpm}$ for $18 \mathrm{~h}$ at $37^{\circ} \mathrm{C}$, followed by centrifugation at $10,000 \mathrm{~g}$ for $15 \mathrm{~min}$. The supernatant was filtered through a $0.22 \mu \mathrm{m}$ membrane and protein concentration was determined by a Bradford assay.

A 65-day-old New Zealand rabbit was immunized intramuscularly with a lyophilized culture supernatant corresponding to $200 \mu \mathrm{g}$ of protein, re-suspended in $1 \mathrm{~mL}$ of distilled water and emulsified with Montanide adjuvant (SEPPIC-France). A booster dose was given after 15 days. Serum samples to be used as a negative control in specific antibody evaluation were obtained just before the first immunization by the auricular-vein method. Serum samples were also obtained 15 days after the last antigen injection and were subsequently analyzed by enzyme linked immunosorbent assay (ELISA) using C3888 supernatant as antigen.

To be depleted of non-related antibodies, the rabbit antiserum was adsorbed against the aEPEC isolate BA86 (the non-haemolytic control) or BA3160 (a cytolysin expressing isolate). Briefly, the bacterial pellet was resuspended in $0.01 \mathrm{M}$ PBS pH 7.2 containing $1 \mathrm{mM}$ phenylmethylsulphonyl fluoride and centrifuged again at $10,000 \mathrm{~g}$ for $15 \mathrm{~min}$. The sample was kept at $-20^{\circ} \mathrm{C}$ until use.

The adsorption procedure was performed by homogenizing the bacterial pellet with $1.5 \mathrm{~mL}$ of the antiserum in $2 \mathrm{~mL}$ microcentrifuge tubes. The sample was agitated for $2 \mathrm{~h}$ at room temperature and then incubated for $16-18 \mathrm{~h}$ at $4^{\circ} \mathrm{C}$. The mixture was then centrifuged at $5,000 \mathrm{~g}$ for $10 \mathrm{~min}$ and the pellet was discarded. This procedure was repeated twice after which the serum was filtered through a $0.22 \mu \mathrm{m}$ membrane. The depleted antiserum was stored at $-20^{\circ} \mathrm{C}$ until use.

ECM components binding assay - All macromolecules were purchased from Sigma Chemical Co Adhesion of proteins from bacterial supernatants to indi- 
vidual macromolecules of ECM was analyzed according to Barbosa et al. (2006). ELISA plate wells (NuncImmuno plate, Maxi Sorp) were coated with $1 \mu \mathrm{g}$ of laminin, collagen type I and IV, cellular fibronectin, plasma fibronectin or matrigel in $100 \mu \mathrm{L}$ of PBS for $2 \mathrm{~h}$ at $37^{\circ} \mathrm{C}$. The wells were washed three times with PBS $0.05 \%$ Tween 20 (PBST) and then blocked with $200 \mu \mathrm{L}$ of $1 \% \mathrm{BSA}$ for $1 \mathrm{~h}$ at $37^{\circ} \mathrm{C}$. Twenty micrograms of protein from the isolates' supernatants were added per well in $100 \mu \mathrm{L}$ of PBS and proteins were allowed to bind to the different ECM substrates for $1.5 \mathrm{~h}$ at $37^{\circ} \mathrm{C}$. The plates were washed three times with PBST, then incubated with anti-supernatant serum diluted 1:5.000 for $1 \mathrm{~h}$. After three washes with PBST, $100 \mu \mathrm{L}$ per well of a 1:10.000 peroxidase-conjugated goat anti-rabbit immunoglobulin G in PBS was added and incubated for $1 \mathrm{~h}$. All incubations were done at $37^{\circ} \mathrm{C}$. The wells were washed three times and $o$-phenylenediamine $(0.04 \%)$ in citrate phosphate buffer ( $\mathrm{pH} 5.0)$ plus $0.01 \%(\mathrm{w} / \mathrm{v}) \mathrm{H}_{2} \mathrm{O}_{2}$ was added. The reaction was allowed to proceed for $15 \mathrm{~min}$ and was then terminated by the addition of $50 \mu \mathrm{L}$ of $8 \mathrm{M} \mathrm{H}_{2} \mathrm{SO}_{4}$. To detect the bound proteins, the absorbance at $492 \mathrm{~nm}$ was measured using a microplate ELISA reader (Labsystems Uniscience, Multiskan EX).

Statistical analysis - The ELISA absorbance $\left(\mathrm{A}_{492 \mathrm{~nm}}\right)$ data from duplicates of three independent experiments were presented as mean and standard error and were analyzed using GraphPad Prism 5.00 ${ }^{\circledR}$ software. Differences were considered significant when $\mathrm{p}<0.05$, by Student $t$ test.

\section{RESULTS}

The phenotypic haemolytic profile of 72 isolates previously defined as aEPEC (Abe et al. 2009) was evaluated. To detect haemolytic activity, all bacteria were taken from stock cultures and spotted onto blood agar plates. Data regarding toxin expression or secretion are associated with the composition of the culture media in which the bacteria are grown (Vilhena-Costa et al. 2006, Rocha \& Piazza 2007). We investigated whether the haemolytic profile of aEPEC isolates was dependent on media components. Therefore, the isolates were precultured in different media (TSB, EM or MM) before being spotted onto blood agar plates.

The isolates 2103 (O26:H11), 2459 (O26:H11), 2775 (O113:H19) and 3160 (O110:HNM) showed haemolytic activity in a narrow zone of haemolysis (Fig. 1A-D). The culture media had no influence on these four haemolytic isolates or the control strain (C3888) (Fig. 1E). In contrast, haemolytic activity was detected in two other strains, 2062 (O171:H48) and 4192 (O11:H25), but only after pre-incubation in MM (Fig. 1F-G, Table I).

We next focused on correlating the haemolytic phenotype with the presence of the ehx, ehly and sheA genes. The presence of $e h x$ and ehly was detected only in two isolates (2103 and 2459) (Tables I, II). In addition, the she $A$ gene was detected in 51 isolates, a prevalence of $70.8 \%$ (Table II). In the C3888 strain, all three genes were detected, confirming previous observations (Oscarsson et al. 2002a).
As an experimental tool for further investigations, we produced a rabbit polyclonal antiserum against proteins from the concentrated supernatant of the prototype strain C3888, which produces Ehlys and ClyA. We used the supernatant to produce the antiserum because the haemolytic activity was detected in the supernatant fraction rather than in the non-disrupted pellet (Fig. 2). This observation differs from previous reports, which describe the lack of haemolytic activity in the culture supernatant of strain C3888 (Beutin et al. 1990, Figueiredo et al. 2003). However, these authors detected such activity in disrupted bacterial cells collected by centrifugation. Haemolytic activity was also detected in concentrated supernatants of isolates BA2103, BA2459, BA2775 and BA3160 (data not shown).

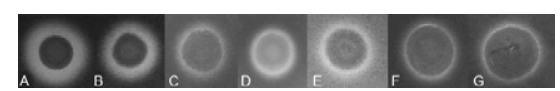

Fig. 1: haemolytic profile of atypical enteropathogenic Escherichia coli (aEPEC) on blood agar plates spotted directly from stock cultures: A: 2103 (O26:H11); B: 2459 (O26:H11); C: 2775 (O113:H19); D: 3160 (O110:HNM); E: C3888 (O26: $\mathrm{H}^{-}$, enterohaemolysin control or spotted after pre-cultivation in minimal medium containing $2 \%$ lactose); F: 2062 (O171:H48); G: 4192 (O51:H48).

\section{TABLE I}

Genotypic features of atypical enteropathogenic Escherichia coli isolates presenting haemolytic activity

\begin{tabular}{lccccccc}
\hline $\begin{array}{l}\text { Bacterial } \\
\text { isolates }\end{array}$ & Serotype & eae & bfp & stx & ehly & ehxA & sheA \\
\hline BA2062 & O171:H40 & + & - & - & - & - & + \\
BA2103 & O26:H11 & + & - & - & + & + & + \\
BA2459 & O26:H11 & + & - & - & + & + & + \\
BA2775 & O113:H19 & + & - & - & - & - & + \\
BA3160 $^{2}$ O110:H- & + & - & - & - & - & + \\
BA4192 $^{a}$ & O111:H25 & + & - & - & - & - & + \\
C3888 $^{2}$ O26:H- & + & - & - & + & + & + \\
\hline
\end{tabular}

$a$ : haemolysis in $24 \mathrm{~h}$ only after pre-cultivated in minimal medium containing $2 \%$ lactose.

\section{TABLE II}

Detection of haemolysin-encoding genes among atypical enteropathogenic Escherichia coli isolates

\begin{tabular}{lc}
\hline Gene & $\begin{array}{c}\text { Positive strains } \\
(\mathrm{n}=72)\end{array}$ \\
\hline ehly & $2 / 72$ \\
ehx & $2 / 72$ \\
sheA & $51 / 72$ \\
\hline
\end{tabular}




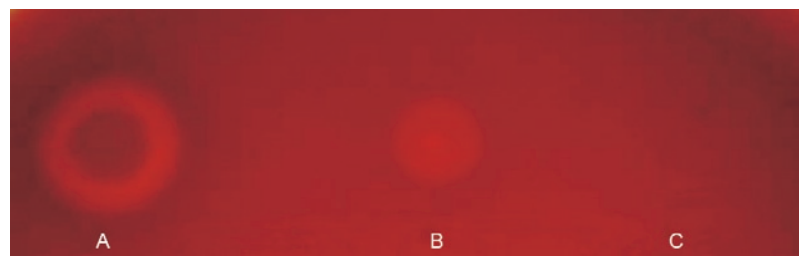

Fig. 2: haemolytic activity on blood agar plates of prototype strain C3888. A: whole bacterial growth; B: concentrated supernatant from bacterial growth; C: non-disrupted pellet.

Using this antiserum, which had been previously adsorbed with the non-haemolytic aEPEC control (strain 86 ), we investigated whether proteins from the supernatant of haemolysin-expressing and non-expressing aEPEC strains would interact with ECM macromolecules. Laminin-1, collagen type I, collagen type IV, cellular fibronectin and plasma fibronectin were immobilized on microdilution wells and protein attachment was assessed by an ELISA-based method.

As can be seen in Fig. 3, proteins from isolates that exhibit the haemolytic phenotype bound to all tested ECM macromolecules. A statistical analysis demonstrated significant differences between the mean binding capacity of haemolytic and non-haemolytic isolates. The strains 2103 and 2459, in which the genes ehly/ehxA and sheA were detected, presented higher binding capacity $\left(\mathrm{A}_{492 \mathrm{~nm}}\right.$ c.a 1) either to laminin ( $\left.\mathrm{p}<0.0001 \mathrm{R}^{2} 0.70\right)$ or to collagen I $\left(\mathrm{p}<0.0001 \mathrm{R}^{2} 0.77\right)$ or to cellular fibronectin $\left(\mathrm{p}<0.0001 \mathrm{R}^{2} 0.72\right)$ than the isolates which contain only sheA (2775 and $3160, \mathrm{~A}_{492 \mathrm{~nm}}$ c.a 0.5). This higher binding capacity was also exhibited by the control strain C3888, which also contains the genes ehly and sheA. In addition, those isolates that showed haemolytic activity only after being pre-cultured in $\mathrm{MM}$ exhibited the lowest binding capacity to ECM molecules (2062 and 4192, $\mathrm{A}_{492 \mathrm{~nm}}$ c.a 0.25 ) (Fig. 3). Furthermore, isolates that did not present haemolytic activity on blood agar plates did not display any binding to ECM components (Fig. 3).

To check the differences between the binding capacity of isolates that express either Ehly and Ehx or ClyA, the antiserum was adsorbed with a ClyA expressing strain (3160). Both antisera were used to perform an ELISA on matrigel (a mixture of laminin, collagen and fibronectin) to compare the reactivity of the 2103, 2459 and C3888 isolates. The differences between the binding capacities of these isolates could be attributed to Ehly and/or Ehx. These data confirm the high ability of the strains that express Ehlys and ClyA to bind to ECM components, as verified by the statistical significance between the two experiments for each strain (2103: $\mathrm{p}=$ 0.01, $R^{2}$ 0.96), (2459: $\mathrm{p}=0.0028, \mathrm{R}^{2}$ 0.99) and (C3888: $\mathrm{p}$ $=0.02, \mathrm{R}^{2}$ 0.94) (Fig. 4).

\section{DISCUSSION}

Recent reports on the aetiology of acute diarrhoea indicate that aEPEC is an emerging DEC pathotype (Hernandes et al. 2009), necessitating epidemiological and virulence studies. Additionally, many questions have
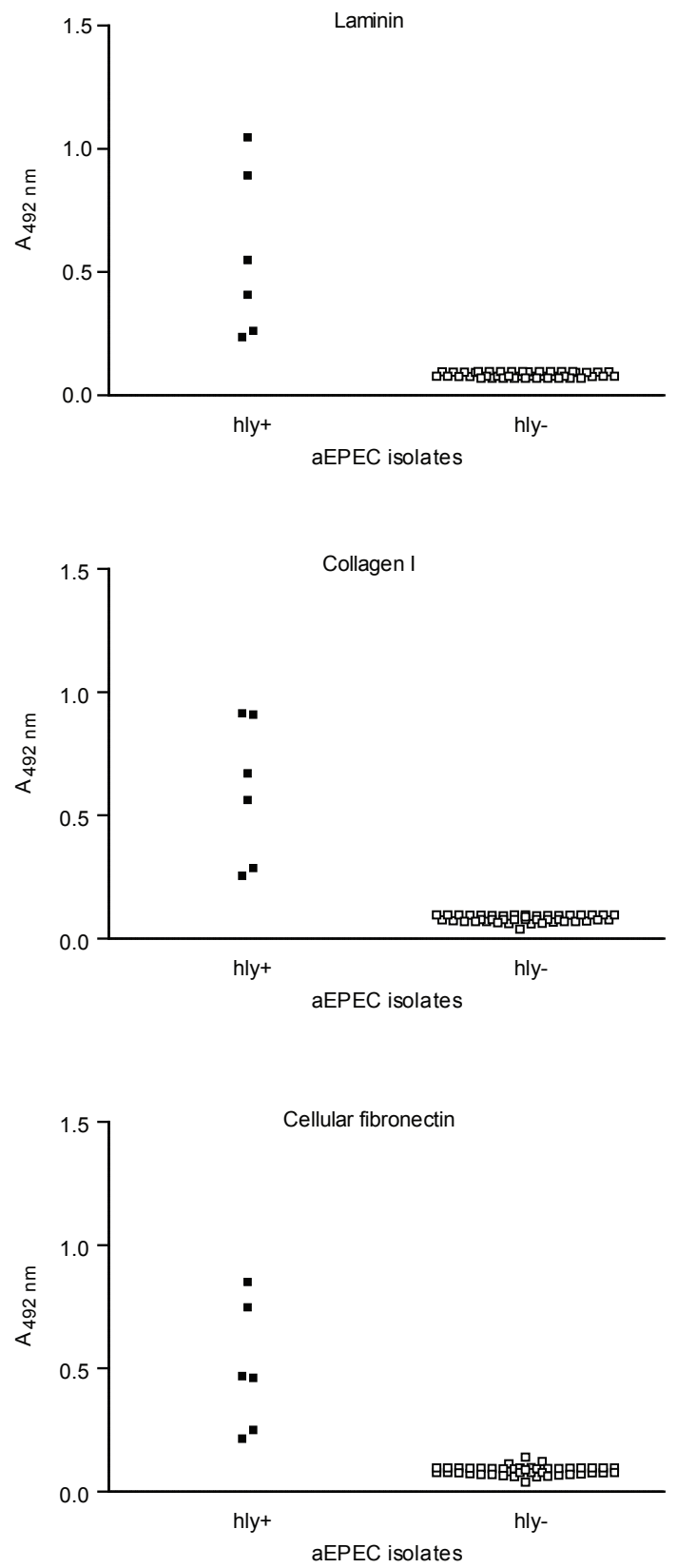

Fig. 3: binding of proteins from bacterial supernatants of atypical enteropathogenic Escherichia coli (aEPEC) isolates to different extracellular matrix macromolecules. Protein adhesiveness was assessed by an enzyme linked immunosorbent assay-based assay and optical densities were determined at $492 \mathrm{~nm}$. $\mathbf{~}$ : haemolytic isolates; $\square$ : nonhaemolytic isolates.

arisen about the additional virulence factors expressed by aEPEC in comparison to tEPEC (Trabulsi et al. 2002, Hernandes et al. 2009). Among these factors are haemolysins, which are widespread among bacterial pathogens, including EHEC, a pathogen that is phylogenetically close to aEPEC (Trabulsi et al. 2002, Bando et al. 2009). In the present work, we assessed the haemolytic profile of aEPEC, which had been isolated in an epidemiological study of acute diarrhoea (Bueris et al. 2007). 


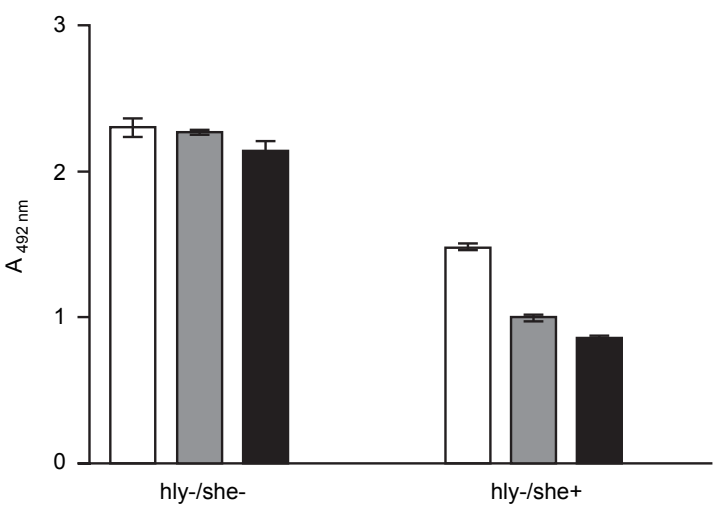

Fig. 4: binding of proteins from bacterial supernatants to matrigel. Protein adhesiveness was assessed by an enzyme linked immunosorbent assay-based assay and optical densities were determined at $492 \mathrm{~nm}$. Bars represent $95 \%$ confidence interval of means and standard deviation of triplicates of three independent experiments with each isolate (black bars: 2459 isolate; grey bars: 2103 isolate; white bars: C3888 isolate). hly-/she-: reactivity with antiserum depleted of non-related antibodies; hly-/she+: reactivity with antiserum depleted of cytolysin A and non-related antibodies.

In six aEPEC isolates, the haemolytic phenotype was observed after precisely $24 \mathrm{~h}$ of incubation on blood agar plates, suggesting that this phenotype was due to Ehlys. However, only two of the isolates were positive for ehxA/ ehlyA genes (BA2103 and BA2459), corroborating recent reports in which the plasmid-encoded Ehly (encoded by ehxA) of EHEC O157:H7 was significantly associated with diarrhoea (Afset et al. 2008, Scaletsky et al. 2009).

The sheA gene has also been detected in pathogenic E. coli, such as STEC, EIEC, EAEC, ETEC (Ludwig et al. 1999) and ExPEC (Kerényi et al. 2005). We also found a high prevalence of the sheA gene in aEPEC, not correlated with the haemolytic activity. Usually ClyA, or "silent haemolysin", causes haemolysis under the following conditions: sheA is present in high-copy-number plasmids, certain sheA regulator genes (mprA and $s l y A)$ are overexpressed (del Castillo et al. 1997), the transcription of the chromosomal sheA is derepressed (Westermark et al. 2000) or other global transcription factors, such as fumarate and nitrate reduction and catabolite gene activator protein, are present (Ralph et al. 1998, Westermark et al. 2000, Wyborn et al. 2004). One of these conditions might explain the haemolytic phenotype of the two isolates in which only the sheA gene was present and haemolysis occurred independently of medium composition (BA2775 and BA3160), whereas in the two others (BA2062 and BA4192), the haemolytic activity was present only when they were previously cultivated in MM, which contains lactose. Because the sheA gene remains silent under the usual laboratory growth conditions (del Castillo et al. 1997), our data would imply that increased lactose concentrations promote an oxidative condition (Gottesman 2004), which would induce ClyA expression. Thus, the data presented here demonstrate that only some of the tested strains express ClyA, which in turn indicates that this toxin can play a role only in a subset of the pathogenic aEPEC.
The main aspect examined in the present study was the capacity of proteins released by both haemolysinexpressing and non-expressing aEPEC strains to interact with ECM components. No specific binding to the target ECM macromolecules was detected with proteins released by strains that did not express haemolysin. In contrast, the ability to bind to ECM molecules by proteins produced by aEPEC strains that did express haemolysin could be categorized in three subsets: (i) high binding capacity shared by those strains in which the ehlyA, ehxA and sheA genes were present, (ii) medium binding capacity present in isolates harbouring the she A gene and also showing haemolytic phenotype under the usual laboratory growth conditions and (iii) low binding capacity exhibited by the strains in which the gene she A is present and the haemolytic phenotype was induced only after pre-cultivation in lactose-containing MM.

The differences in binding capacity amongst the haemolytic isolates, which was detected when an antiserum depleted of SheA antibodies was used, suggest that the remaining binding activity to ECM observed in supernatants of isolates BA2103, BA2459 and C3888 can be attributed to EhxA and/or Ehly activity. Further experiments, currently under way in our laboratory, will clarify the role of these haemolysins.

Although cytolytic toxins are considered to be virulence factors and are found in disease-causing bacteria, their precise contribution to pathogenesis is not completely understood. In some Salmonella enterica serovars, including Salmonella Typhi, HlyE (ClyA or SheA) (Fuentes et al. 2008), was described as a pore-forming haemolysin that accumulates in the $S$. Typhi periplasm and can be artificially released by destabilizing the bacterial envelope (Oscarsson et al. 2002b, Fuentes et al. 2008). Purified E. coli HlyE is cytotoxic to mammalian cells and the functional transfer of $S$. Typhi HlyE to Salmonella typhimurium promotes deep organ infection in mice (Lai et al. 2000, Oscarsson et al. 2002b, Fuentes et al. 2008). The capacity of proteins secreted by haemolysin-expressing aEPEC isolates to bind to ECM, described here for the first time, represents one more piece in the complicated pathogenesis mechanism of aEPEC. These data suggest that the adhesion of haemolysins to matrix macromolecules might contribute to a second step in this process, as already described for other pathogens (Matsunaga et al. 2003, Liang \& Ji 2006).

In conclusion, the data presented in this study demonstrate that a subset of aEPEC presents haemolytic activity due to Ehly and/or ClyA. This activity involves the binding of proteins released by these isolates to ECM components, suggesting that these haemolysins can play a role in pathogenesis.

\section{ACKNOWLEDGEMENTS}

To Dr Claudia Trigo Pedroso de Moraes, for technical support.

\section{REFERENCES}

Abe CM, Trabulsi LR, Blanco J, Blanco M, Dahbi G, Blanco JE, Mora A, Franzolin MR, Taddei CR, Martinez MB, Piazza RM, Elias WP 2009. Virulence features of atypical enteropathogenic Escherichia coli identified by the eae $(+)$ EAF-negative stx(-) genetic profile. Diagn Microbiol Infect Dis 64: 357-365. 
Afset JE, Anderssen E, Bruant G, Harel J, Wieler L, Bergh K 2008. Phylogenetic backgrounds and virulence profiles of atypical enteropathogenic Escherichia coli strains from a case-control study using multilocus sequence typing and DNA microarray analysis. J Clin Microbiol 46: 2280-2290.

Afset JE, Bevanger L, Romundstad P, Bergh K 2004. Association of atypical enteropathogenic Escherichia coli (EPEC) with prolonged diarrhoea. J Med Microbiol 53: 1137-1144.

Alouf JE 2001. Pore-forming bacterial protein toxins: an overview. Curr Top Microbiol Immunol 257: 1-14.

Bando SY, Andrade FB, Guth BE, Elias WP, Moreira-Filho CA, Pestana de Castro AF 2009. Atypical enteropathogenic Escherichia coli genomic background allows the acquisition of nonEPEC virulence factors. FEMS Microbiol Lett 299: 22-30.

Barbosa AS, Abreu PA, Neves FO, Atzingen MV, Watanabe MM, Vieira ML, Morais ZM, Vasconcellos SA, Nascimento AL 2006. A newly identified leptospiral adhesin mediates attachment to laminin. Infect Immun 74: 6356-6364.

Bauer ME, Welch RA 1996. Characterization of an RTX toxin from enterohemorrhagic Escherichia coli O157:H7. Infect Immun 64: $167-175$.

Beutin L, Bode L, Ozel M, Stephan R 1990. Enterohemolysin production is associated with a temperate bacteriophage in Escherichia coli serogroup O26 strains. J Bacteriol 172: 6469-6475.

Beutin L, Montenegro MA, Orskov I, Orskov F, Prada J, Zimmermann S, Stephan R 1989. Close association of verotoxin (Shigalike toxin) production with enterohemolysin production in strains of Escherichia coli. J Clin Microbiol 27: 2559-2564.

Beutin L, Prada J, Zimmermann S, Stephan R, Orskov I, Orskov F 1988. Enterohemolysin, a new type of hemolysin produced by some strains of enteropathogenic E. coli (EPEC). Zentralbl Bakteriol Mikrobiol Hyg A 267: 576-588.

Bueris V, Sircili MP, Taddei CR, Santos MF, Franzolin MR, Martinez MB, Ferrer SR, Barreto ML, Trabulsi LR 2007. Detection of diarrheagenic Escherichia coli from children with and without diarrhea in Salvador, Bahia, Brazil. Mem Inst Oswaldo Cruz 102: 839-844.

Cookson AL, Bennett J, Thomson-Carter F, Attwood GT 2007. Molecular subtyping and genetic analysis of the enterohemolysin gene (ehxA) from Shiga toxin-producing Escherichia coli and atypical enteropathogenic E. coli. Appl Environ Microbiol 73: 6360-6369.

del Castillo FJ, Leal SC, Moreno F, del Castillo I 1997. The Escherichia coli K-12 sheA gene encodes a 34-kDa secreted haemolysin. Mol Microbiol 25: 107-115.

Donnenberg MS, Girón JA, Nataro JP, Kaper JB 1992. A plasmid-encoded type IV fimbrial gene of enteropathogenic Escherichia coli associated with localized adherence. Mol Microbiol 6: 3427-3437.

Estrada-Garcia T, Lopez-Saucedo C, Thompson-Bonilla R, Abonce M, Lopez-Hernandez D, Santos JI, Rosado JL, DuPont HL, Long KZ 2009. Association of diarrheagenic Escherichia coli pathotypes with infection and diarrhea among Mexican children and association of atypical enteropathogenic $E$. coli with acute diarrhea. J Clin Microbiol 47: 93-98.

Figueiredo PM, Catani CF, Yano T 2003. Thiol-independent activity of a cholesterol-binding enterohemolysin produced by enteropathogenic Escherichia coli. Braz J Med Biol Res 36: 1495-1499.

Franzolin MR, Alves RCB, Keller R, Gomes TAT, Beutin L, Barreto ML, Milroy C, Strina A, Ribeiro H, Trabulsi LR 2005. Prevalence of diarrheagenic Escherichia coli in children with diarrhea in Salvador, Bahia, Brazil. Mem Inst Oswaldo Cruz 100: 359-363.
Fuentes JA, Villagra N, Castillo-Ruiz M, Mora GC 2008. The Salmonella Typhi $h l y E$ gene plays a role in invasion of cultured epithelial cells and its functional transfer to $S$. typhimurium promotes deep organ infection in mice. Res Microbiol 159: 279-287.

Gottesman S 2004. The small RNA regulators of Escherichia coli: roles and mechanisms. Annu Rev Microbiol 58: 303-328.

Hacker J, Hughes C, Hof H, Goebel W 1983. Cloned hemolysin genes from Escherichia coli that cause urinary tract infection determine different levels of toxicity in mice. Infect Immun 42: 57-63.

Hernandes RT, Elias WP, Vieira MA, Gomes TA 2009. An overview of atypical enteropathogenic Escherichia coli. FEMS Microbiol Lett 297: 137-149.

Hull RA, Gill RE, Hsu P, Minshew BH, Falkow S 1981. Construction and expression of recombinant plasmids encoding type 1 or Dmannose-resistant pili from a urinary tract infection Escherichia coli isolate. Infect Immun 33: 933-938.

Jenkins C, Evans J, Chart H, Willshaw GA, Frankel G 2008. Escherichia coli serogroup O26: a new look at an old adversary. $J$ Appl Microbiol 104: 14-25.

Kaper JB 1996. Defining EPEC. Rev Microbiol 27 (Suppl. 1): 130-133.

Kerényi M, Allison HE, Bátai I, Sonnevend A, Emödy L, Plaveczky N, Pál T 2005. Ocurrence of hlyA and sheA genes in extraintestinal Escherichia coli strains. J Clin Microbiol 43: 2965-2968.

Lai XH, Arencibia I, Johansson A, Wai SN, Oscarsson J, Kalfas S, Sundqvist KG, Mizunoe Y, Sjöstedt A, Uhlin BE 2000. Cytocidal and apoptotic effects of the ClyA protein from Escherichia coli on primary and cultured monocytes and macrophages. Infect Immun 68: 4363-4367.

Liang X, Ji Y 2006. Alpha-toxin interferes with integrin-mediated adhesion and internalization of Staphylococcus aureus by epithelial cells. Cell Microbiol 8: 1656-1668.

Lowrance JH, Hasty DL, Simpson WA 1988. Adherence of Streptococcus sanguis to conformationally specific determinants in fibronectin. Infect Immun 56: 2279-2285.

Ludwig A, Bauer S, Benz R, Bergmann B, Goebel W 1999. Analysis of the SlyA-controlled expression, subcellular localization and pore-forming activity of a $34 \mathrm{kDa}$ haemolysin (ClyA) from Escherichia coli K-12. Mol Microbiol 31: 557-567.

Matsunaga J, Barocchi MA, Croda J, Young TA, Sanchez Y, Siqueira I, Bolin CA, Reis MG, Riley LW, Haake DA, Ko AI 2003. Pathogenic Leptospira species express surface-exposed proteins belonging to the bacterial immunoglobulin superfamily. Mol Microbiol 49: 929-945.

McDaniel TK, Kaper JB 1997. A cloned pathogenicity island from enteropathogenic Escherichia coli confers the attaching and effacing phenotype on E. coli K-12. Mol Microbiol 23: 399-407.

Moreno AC, Filho AF, Gomes T do A, Ramos ST, Montemor LP, Tavares VC, Filho L dos Santos L, Irino K, Martinez MB 2010. Etiology of childhood diarrhea in the northeast of Brazil: significant emergent diarrheal pathogens. Diagn Microbiol Infect Dis 66: 50-57.

Nara JM, Cianciarullo AM, Culler HF, Bueris V, Horton DS, Menezes MA, Franzolin MR, Elias WP, Piazza RM 2010. Differentiation of typical and atypical enteropathogenic Escherichia coli using colony immunoblot for detection of bundle-forming pilus expression. J Appl Microbiol 109: 35-43.

Nguyen RN, Taylor LS, Tauschek M, Robins-Browne RM 2006. Atypical enteropathogenic Escherichia coli infection and prolonged diarrhea in children. Emerg Infect Dis 12: 597-603.

Oscarsson J, Mizunoe Y, Uhlin BE, Haydon DJ 1996. Induction of haemolytic activity in Escherichia coli by the slyA gene product. Mol Microbiol 20: 191-199. 
Oscarsson J, Westermark M, Beutin L, Uhlin BE 2002a. The bacteriophage-associated ehly1 and ehly2 determinants from Escherichia coli $\mathrm{O} 26: \mathrm{H}^{-}$strains do not encode enterohemolysins per se but cause release of the ClyA cytolysin. Int J Med Microbiol 291: 625-631.

Oscarsson J, Westermark M, Löfdahl S, Olsen B, Palmgren H, Mizunoe Y, Wai SN, Uhlin BE 2002b. Characterization of a poreforming cytotoxin expressed by Salmonella enterica serovars Typhi and paratyphi A. Infect Immun 70: 5759-5769.

Ralph ET, Guest JR, Green J 1998. Altering the anaerobic transcription factor FNR confers a hemolytic phenotype on Escherichia coli K12. Proc Natl Acad Sci USA 95: 10449-10452.

Robins-Browne RM, Bordun AM, Tauschek M, Bennett-Wood VR, Russell J, Oppedisano F, Lister NA, Bettelheim KA, Fairley CK, Sinclair MI, Hellard ME 2004. Escherichia coli and community acquired gastroenteritis, Melbourne, Australia. Emerg Infect Dis 10: 1797-1805.

Rocha LB, Piazza RM 2007. Production of Shiga toxin by Shiga toxin-expressing Escherichia coli (STEC) in broth media: from divergence to definition. Lett Appl Microbiol 45: 411-417.
Scaletsky IC, Aranda KR, Souza TB, Silva NP, Morais MB 2009. Evidence of pathogenic subgroups among atypical enteropathogenic Escherichia coli strains. J Clin Microbiol 47: 3756-3759.

Schmidt H, Maier E, Karch H, Benz R 1996. Pore-forming properties of the plasmid-encoded hemolysin of enterohemorrhagic Escherichia coli O157:H7. Eur J Biochem 241: 594-601.

Trabulsi LR, Keller R, Tardelli Gomes TA 2002. Typical and atypical enteropathogenic Escherichia coli. Emerg Infect Dis 8: 508-513.

Vilhena-Costa AB, Piazza RM, Nara JM, Trabulsi LR, Martinez MB 2006. Slot blot immunoassay as a tool for plasmid-encoded toxin detection in enteroaggregative Escherichia coli culture supernatants. Diagn Microbiol Infect Dis 55: 101-106.

Westermark M, Oscarsson J, Mizunoe Y, Urbonaviciene J, Uhlin BE 2000. Silencing and activation of ClyA cytotoxin expression in Escherichia coli. J Bacteriol 182: 6347-6357.

Wyborn NR, Clark A, Roberts RE, Jamieson SJ, Tzokov S, Bullough PA, Stillman TJ, Artymiuk PJ, Galen JE, Zhao L, Levine MM, Green J 2004. Properties of haemolysin E (HlyE) from a pathogenic Escherichia coli avian isolate and studies of HlyE export. Microbiology 150: 1495-1505. 